\title{
Mammalian foetal ovarian development: consequences for health and disease
}

\author{
Mai A Sarraj and Ann E Drummond \\ Prince Henry's Institute, PO Box 5152, Clayton, Victoria 3168, Australia \\ Correspondence should be addressed to M A Sarraj; Email: mai.sarraj@princehenrys.org
}

\begin{abstract}
The development of a normal ovary during foetal life is essential for the production and ovulation of a high-quality oocyte in adult life. Early in embryogenesis, the primordial germ cells (PGCs) migrate to and colonise the genital ridges. Once the PGCs reach the bipotential gonad, the absence of the sex-determining region on the $Y$ chromosome ( $S R Y$ ) gene and the presence of female-specific genes ensure that the indifferent gonad takes the female pathway and an ovary forms. PGCs enter into meiosis, transform into oogonia and ultimately give rise to oocytes that are later surrounded by granulosa cells to form primordial follicles. Various genes and signals are implicated in germ and somatic cell development, leading to successful follicle formation and normal ovarian development. This review focuses on the differentiation events, cellular processes and molecular mechanisms essential for foetal ovarian development in the mice and humans. A better understanding of these early cellular and morphological events will facilitate further study into the regulation of oocyte development, manifestation of ovarian disease and basis of female infertility.

Reproduction (2012) 143 151-163
\end{abstract}

\section{Introduction}

Normal ovarian development during embryogenesis is the key to fertility and reproductive success later in life. In mammals, reproductive capacity is limited by the size of the non-renewable pool of oocytes, which is established during foetal life. Follicles, the basic unit of the ovary, house the oocytes and are essential for their development and survival (Byskov 1986). In the early stages of development, follicles consist of an oocyte surrounded by somatic granulosa cells and the extracellular matrix (ECM; Fig. 1). As the follicle grows and differentiates, theca cells are recruited; these cells are the source of the oestrogen substrate, androstenedione (reviewed in Edson et al. (2009)). Each month throughout the course of a female's reproductive life, primordial follicles are activated to begin follicle development. This process culminates in a follicle that contains a mature fertilisable oocyte ready for release at ovulation. Disturbances in the initial steps or processes that facilitate foetal ovarian differentiation result in incomplete sexual development and may contribute to childhood and adult diseases such as gonadal dysgenesis, infertility or ovarian cancer (de Boo \& Harding 2006). This review discusses the highly regulated, unique processes and genetic mechanisms required for normal ovarian development. It is these events during foetal development that determine the fertility and reproductive capacity of the adult individual (Fig. 2).

\section{Beginnings of the ovary}

One of the earliest events in embryonic development is $\mathrm{X}$ chromosome inactivation, a process that occurs at the two-cell stage of the zygote and enables males and females to have equal transcript levels by genetic inactivation of one of the two $X$ chromosomes in females. In mice, between the four- and eight-cell stage, inactivation of the paternally inherited $X$ chromosome occurs in all female somatic cells (Huynh \& Lee 2001). In the developing germ line, $X$ inactivation is reactivated in primordial germ cells (PGCs) such that both $\mathrm{X}$ chromosomes are active in oogenesis (Sugimoto $\&$ Abe 2007). Epigenetic regulation of gene expression is an essential part of organogenesis and leads to heritable changes in gene function without inducing a change in the DNA sequence. DNA methylation or histone acetylation can affect such changes. The study of epigenetic events in the oocyte is an expanding field of research and involves studying the biology behind developmental processes such as genomic imprinting, $X$ inactivation and transcriptional repression.

In the mouse embryo, oocytes develop from PGCs, which migrate into the extraembryonic mesoderm from about 6 days post coitus (dpc; Fig. 2; Tam \& Zhou 1996). By $7.5 \mathrm{dpc}$, the germ cell pool is located in the allantois (yolk sac; Lawson \& Hage 1994). Various genes and factors are involved in germ cell specification such as the pluripotency marker POU class 5 homeobox 1 

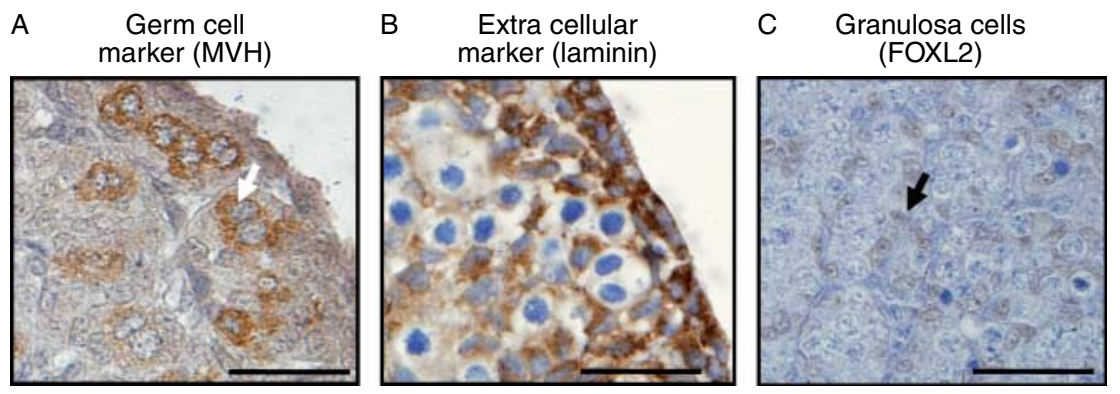
Figure 1 Localisation of cell markers to ovarian structures. Mouse ovarian sections were subject to immunohistochemistry with antibodies for the following: (A) mouse vasa homologue (MVH), which stains the oocytes at $14.5 \mathrm{dpc}$ (white arrow). (B) Laminin, which stains the extra- cellular matrix of the foetal ovary at $14.5 \mathrm{dpc}$ (brown). (C) FOXL2, which stains the granulosa cells surrounding the oocytes at $15.5 \mathrm{dpc}$ (black arrow). Scale bar $=0.5 \mu \mathrm{M}$.

(POU5F1/Oct4) and bone morphogenic proteins 4 and 8 (BMP4 and BMP8; Yoshimizu et al. 2001). Between 9 and $10.5 \mathrm{dpc}$ in the mouse, the PGCs migrate from the yolk sac to colonise the gonadal (genital) ridge (Wylie 1999). The genital ridge is identical in both males and females and remains 'bipotential' until $11.5 \mathrm{dpc}$ in the mouse (Figs 2 and $3 \mathrm{~A}$ ). In humans, PGCs proliferate and migrate into the mesoderm colonising the genital ridges until the 6th week of pregnancy (Baker 1963, Anderson et al. 1999). The gonads are indifferent but bipotential from 7 weeks of gestation until sex is determined (Fig. 4).

In the absence of the sex-determining region on the $Y$ chromosome $(S R Y)$ gene or its downstream target $S R Y$ (sex-determining region-Y)-box 9 (SOX9) (Sinclair et al. 1990, Koopman 1992), and in the presence of genes such as wingless-type MMTV integration site family, member 4 (WNT4), follistatin (FST) and forkhead box L2 (FOXL2), which have been independently implicated in female sex determination, the bipotential gonad forms an ovary and PGCs differentiate into oogonia (Fig. 5). No single regulatory gene 'switch' has been found to activate the ovarian differentiation pathway; however, various models of ovarian development have been put forward. The ovary-determining gene $(\mathrm{Od})$ hypothesis ascribes to a gene located either on the $X$ chromosome or on an autosomal chromosome that activates ovarian differentiation (Eicher \& Washburn 1986). The ' $Z$ model' proposes the existence of a factor that acts by suppressing pro-testis events in genetic males while promoting femaleness in the ovary (McElreavy et al. 1992, also reviewed in Ottolenghi et al. (2007)). Recent advances in the field indicate that normal ovarian development requires both genes that lead to activation of the female pathway and genes that suppress the male pathway. The complex functional relationships between these genes and the pathways involved need to be clarified.

\section{Differentiation events leading to a normal ovary}

In mice, it is not until birth that the oocytes become enclosed in follicles. Before birth, foetal ovarian PGCs develop in cyst-like clusters following colonisation of the genital ridge (Byskov 1986). The mouse gonads are surrounded by the mesonephroi that, at the bipotential stage $(11.5 \mathrm{dpc})$, harbour both the Müllerian and the Wolffian ducts (Fig. 3). The Müllerian duct gives rise to the oviduct, uterus, cervix and upper part of the vagina, while the Wolffian duct differentiates into the epididymis, vas deferens and seminal vesicle (Behringer 1994). After sex determination, the Müllerian duct is maintained in the ovary while the Wolffian duct regresses (Fig. 3).

In the mouse, between 10.5 and $13.5 \mathrm{dpc}$, the germ cells undergo mitosis and become closely associated in clusters called germ cell cysts (Figs 2 and 4). By $13.5 \mathrm{dpc}$, oogonia cease dividing and enter into meiosis to form oocytes. By $14.5 \mathrm{dpc}$, oocytes associate with gonadal somatic pre-granulosa cells to form 'ovigerous cords', loose foetal epithelial structures made up of clusters of pre-granulosa cells and meiotic germ cells (Odor \& Blandau 1969, Pepling \& Spradling 1998, Mazaud et al. 2005, Figs 1 and 4). The role of cyst and ovarian cord

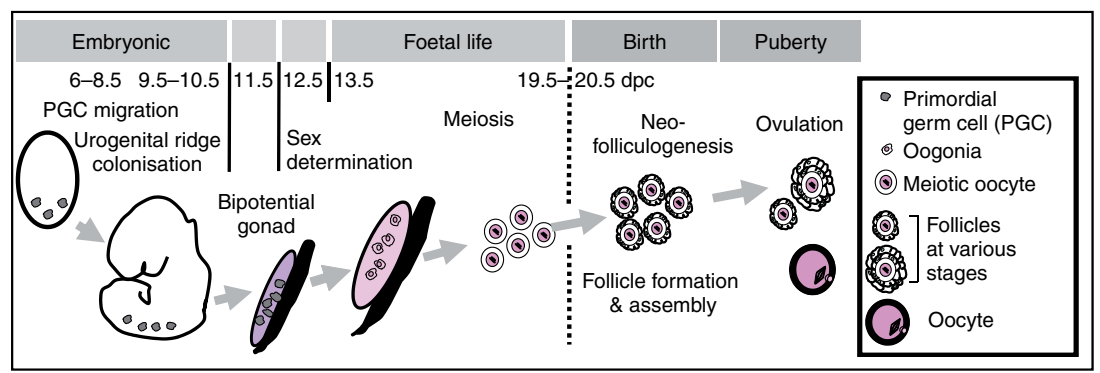

Figure 2 Healthy foetal gonadal development: the path to fertility. Normal oocyte formation is critically dependent on the stages occurring from the primordial germ cells (PGCs). Mouse PGCs migrate along the hindgut until they reach the genital ridges at $10.5 \mathrm{dpc}$. PGCs undergo cell division in the bipotential gonads (11.5 dpc) until sex determination ( $12.5 \mathrm{dpc}$ ). In females, PGCs enter meiosis at $13.5 \mathrm{dpc}$, become oocytes and then progress through prophase I and arrest until birth. After birth, primordial follicles form and folliculogenesis ensues; ovulation occurs once puberty is attained. 

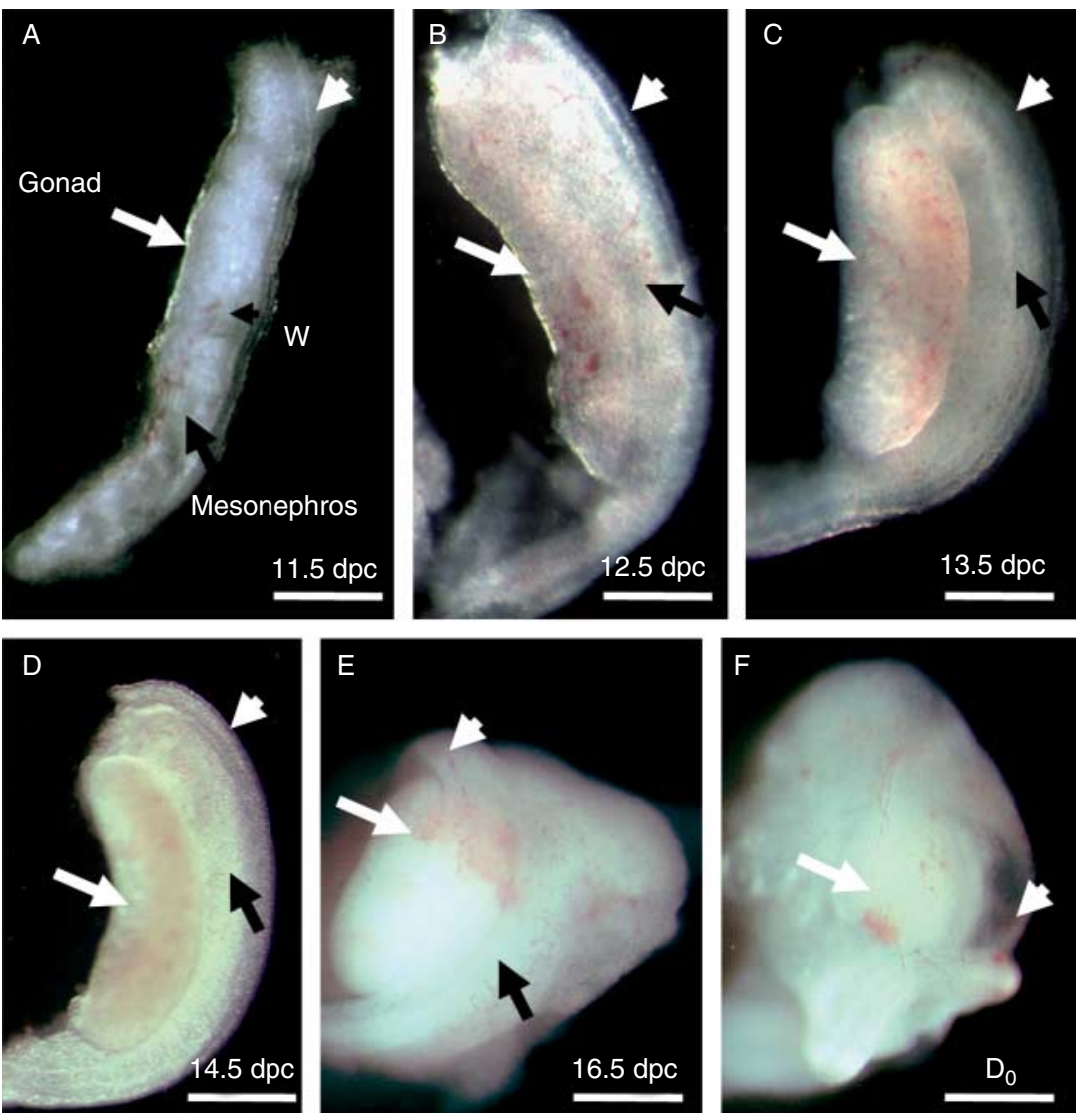

Figure 3 Dissected foetal mouse ovary and mesonephros complexes from the bipotential gonad up until the day of birth. (A) $11.5 \mathrm{dpc}$, (B) $12.5 \mathrm{dpc},(\mathrm{C}) 13.5 \mathrm{dpc}$, (D) $14.5 \mathrm{dpc}$, (E) 16.5 dpc and (F) day of birth $D_{0}$. White arrow points to gonads, black arrow to mesonephros, white arrow head to Müllerian duct and black arrow head to Wolffian duct. Scale bar $=0.5 \mathrm{mM}$. formation in mammalian oocyte development and female fertility is still unclear. However, clues from Drosophila indicate that cyst formation occurs as a result of incomplete cytokinesis during mitosis, allowing daughter cells to connect to each other by intercellular bridges (McKearin \& Ohlstein 1995). One of the essential functions of the cysts in Drosophila is that both oocytes and nurse cells that support the oocyte arise from them (Spradling 1993). Pepling et al. (1999) demonstrated that cysts were highly conserved across species such as Xenopus, Drosophila and the mouse. Suggested functions for cyst formation included: altering the cell

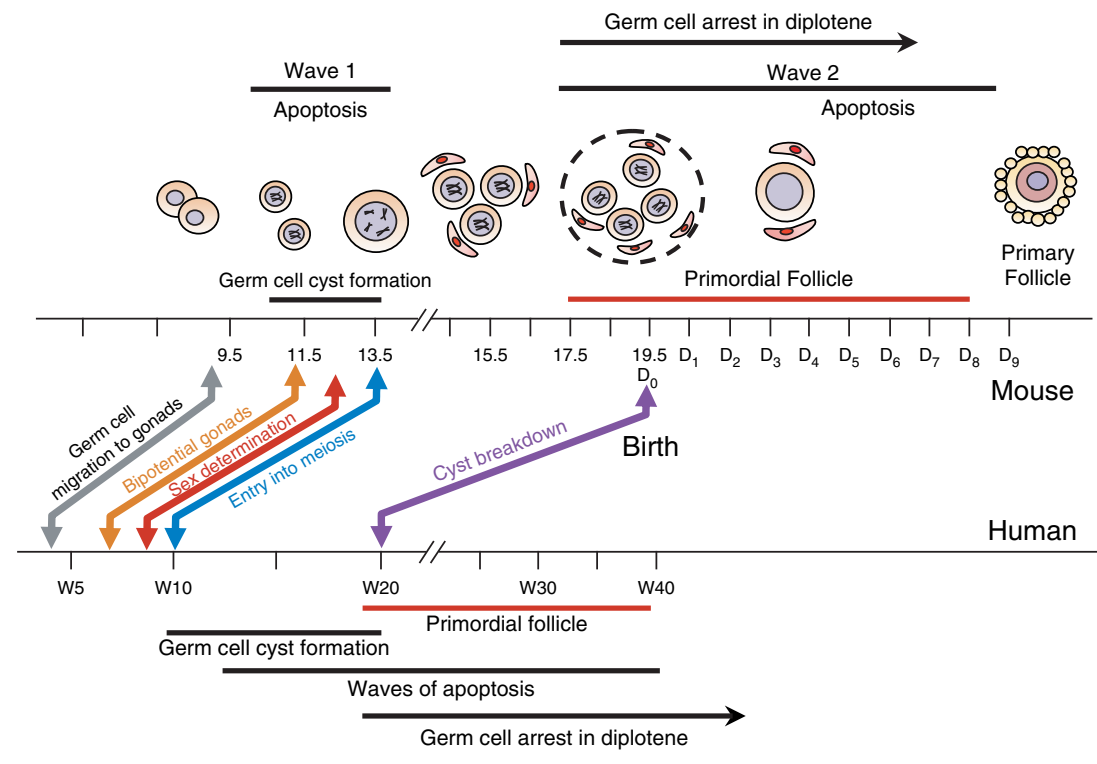

Figure 4 Mouse and human timelines for major processes taking place during foetal development (as reviewed in Pepling (2006) and Hartshorne et al. (2009)). This diagram is a schematic representation of the various processes occurring during mouse and human oogenesis starting from the migration of the PGC into the gonadal ridges until folliculogenesis commences. The mouse timeline is represented in dpc (days post coitus) while the human timeline is represented in $\mathrm{W}$ (weeks post coitus). $\mathrm{D}_{0}$ is the day of birth in the mouse. 


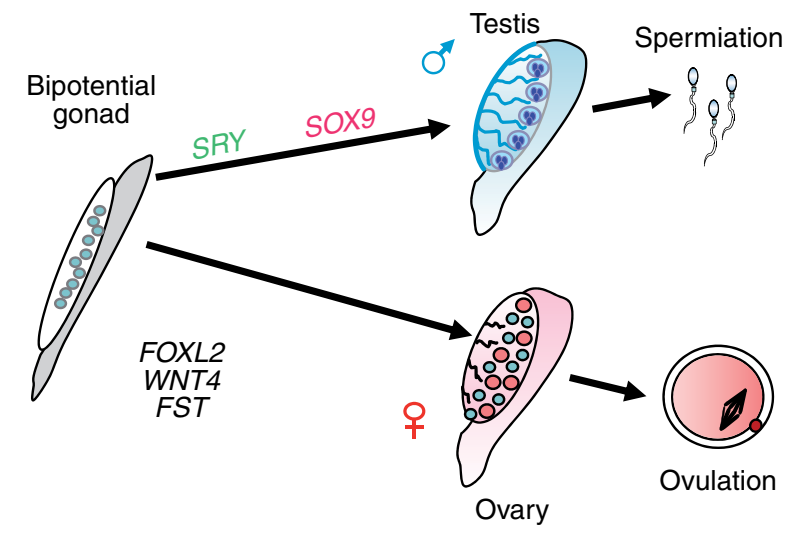

Figure 5 Ovary and testis differentiation from the bipotential gonad. The ovary and testis arise from the bipotential gonad. In the presence of the sex-determining region on the $\mathrm{Y}$ chromosome gene $(S R Y)$ and various male-specific genes such as SOX9, the gonad differentiates into a testis. In the absence of Sry and in the presence of female-specific genes such as FOXL2, WNT4 and FST, the bipotential gonad differentiates into an ovary.

cycle and facilitating meiosis (Hawkins et al. 1996); determining germline sex (Pauli \& Mahowald 1990) and enabling oocytes destined to form primordial follicles to acquire functional mitochondria (Jenuth et al. 1996). Recently, Nicholas et al. (2010) examined whether foetal ovarian cord structures are required for oocyte development. They observed that transplantation of disrupted and re-aggregated foetal ovarian cells from 13.5 to 15.5 dpc mouse embryos, under the kidney capsule of immunodeficient mouse recipients, resulted in a reduced number of oocytes (Nicholas et al. 2010). This study emphasised the importance of an intact ovarian structure during the window of development between 13.5 and $16.5 \mathrm{dpc}$ for programming oocyte survival in mouse follicles after birth.

After birth, the first wave of folliculogenesis ensues, the granulosa cells become organised around the oocytes and the basement membrane undergoes remodelling (Pepling \& Spradling 2001; Fig. 4). The ECM (Fig. 1B) is believed to play an essential role in maintaining cell-tocell interactions and communication necessary for follicle formation and development within the ovary (reviewed in Woodruff \& Shea (2007)). Further studies are required to clarify the mechanisms that regulate the differentiation of germ cells into normal oocytes, initiate cyst formation and elucidate the role of the ECM in ovarian development (Fig. 1). Transgenic and knockout mouse models, either conventional or conditional, continue to provide a wealth of information on early prenatal and post-natal ovarian development. In spite of the differences in temporal and spatial localisation of genes and proteins between the mice and humans (Fig. 4), common processes are involved in ovarian development, making knowledge from the mouse ovary informative for the humans (as will be further discussed).

\section{Processes involved in mouse and human ovarian development}

\section{Organisation of follicular structures in the ovary}

In humans, two processes are fulfilled during foetal ovarian development and before birth: the ovarian endowment of primordial follicles and the recruitment of resting primordial follicles into the growing follicle population (Fig. 4). In contrast, in the rodent, the majority of follicles form and are recruited to grow to primary/more advanced follicles after birth, although there is emerging evidence that follicles start to form at $17.5 \mathrm{dpc}$ (Pepling et al. 2010). In both human and rodent species, follicle growth continues until the primordial follicle population is depleted (Peters et al. 1978, Gougeon 1996).

\section{Entry into meiosis}

Around the time of sex differentiation $(12.5 \mathrm{dpc}$ in the mouse (Fig. 3B) and 6-7 weeks of gestation in the human), germ cells enter a pre-meiotic state within the foetal ovarian germ cell nests (Motta et al. 1997). This time point marks the beginning of expression of the synaptonemal complex protein 3 (Sycp3) gene that encodes for the SYCP, a meiosis-specific protein that facilitates DNA synapses and meiotic recombination. Entry into meiosis occurs in a rostral to caudal (anterior to posterior) fashion in the mouse ovary reflecting the possibility that local factors and cues diffuse from the mesonephros at the anterior code of the ovary to promote meiosis (Bullejos \& Koopman 2004). Once the germ cells enter meiosis, they initiate a relationship with the proximal somatic cells that will later differentiate into two subsets of granulosa cells: mural granulosa and cumulus cells (Matzuk \& Lamb 2002). At $13.5 \mathrm{dpc}$ in the mouse (Adams \& McLaren 2002) and between 8 and 13 weeks in the human foetus (Baker 1963), meiosis is initiated, allowing oogonia to develop into oocytes (Figs 2 and 4). A large number of the oocytes undergo cell death while the remaining oocytes progress through prophase I of meiosis and arrest at diplotene (once primordial follicles are formed); here they remain until ovulation occurs (Borum 1967). A remarkable feature of primordial follicles is that many of them remain dormant for years or decades. Mutations or inactivation of genes known to affect the initial stages of meiosis such as meiotic control 1 (DMC1) and meiosis-specific sporulation protein (SPO11) result in the loss of oocytes and an inability to form follicles resulting in sterility (Villeneuve \& Hillers 2001). Thus, the appropriate initiation of meiosis is essential for oocyte survival (Fig. 2).

Retinoic acid (RA), the active derivative of vitamin A, was identified as a key molecule promoting oogonia in the foetal mouse ovary to enter into meiosis and become oocytes (Bowles et al. 2006, Koubova et al. 2006; also 
reviewed in Bowles \& Koopman (2007)). RA was suggested to either directly or indirectly up-regulate the gene stimulated by retinoic acid gene 8 homolog (Stra8), which encodes a protein essential for pre-meiotic DNA replication. In contrast, in the foetal mouse testis, RA is degraded by the enzyme Cyp26b1 that prevents meiosis from occurring at $13.5 \mathrm{dpc}$.

More recently, a study investigated mice that were incapable of RA synthesis and found that Stra 8 expression in the foetal ovary did not require RA signalling (Kumar et al. 2011) and that Cyp26b1 prevented the onset of meiosis by a mechanism independent of RA. This finding will open new avenues for investigating the role of Cyp26b1 in meiosis.

Germ cells in the human foetal ovary do not enter meiosis in a rostral to caudal wave (Anderson et al. 2007) as they do in the mouse. Instead, the germ cells are arranged radially with undifferentiated PGCs located at the periphery of the ovary and the more differentiated germ cells confined to the centre, suggesting that local control of germ cell differentiation is important in the human foetal ovary. Recently, Childs et al. (2011) characterised the components of RA signalling in the human foetal ovary using cultured foetal gonads. They demonstrated that meiotic initiation may not be exclusively controlled by RA metabolism. Furthermore, they identified differences between humans and mice in regulating the initiation of meiosis in the ovary by RA. This leaves the field in a controversial state that requires further clarification.

\section{Breakdown of oocyte cysts, oocyte loss and primordial follicle formation}

Oocytes entering meiosis are clustered in cysts (as discussed previously) and lack close association with pre-granulosa cells (Gondos 1987, Pepling 2006; Fig. 4). Not all of the oocytes within these cysts survive to form follicles, some die leaving only one or two oocytes (Pepling \& Spradling 2001). Regulation of oocyte numbers is an important process that occurs by cyst breakdown. Around the time of birth in the mouse and after 20 weeks of gestation in humans, the cysts breakdown so that primordial follicles could form (Fig. 4). The primordial follicles comprised oocytes surrounded by a single layer of squamous granulosa cells (Fig. 1).

Only one-third of the oocyte pool forms primordial follicles (Pepling et al. 2010), the remaining oocytes undergo apoptosis perinatally in mice or prenatally in humans (McGee et al. 1998). The fate of oocytes that are incorporated into primordial follicles is controlled by the oocyte; this is in contrast to the growing follicles that are controlled by somatic cell apoptosis (Fig. 4). Germ cell loss during oogenesis occurs through programmed cell death (PCD). Three types of PCD have been described in the ovary: type I, apoptosis characterised by nuclear condensation, fragmentation, cleavage of chromosomal DNA, shrinkage and packaging of the dying cell into apoptotic bodies without plasma membrane breakdown (Edinger \& Thompson 2004); type II, autophagy or lysosomal degradation involving vacuole formation (Tilly 2001) and type III, non-lysosomal degradation involving necrosis characterised by plasma membrane breakdown, alteration in permeability of the cellular membrane, disruption of cytoplasmic structures and nuclear degeneration (Edinger \& Thompson 2004).

In the mouse ovary, cell death by apoptosis is an essential component of ovarian development, which occurs at all stages of oogenesis with two main waves documented during foetal life (reviewed in Aitken et al. (2011)). The first wave of cell death coincides with the entry of oogonia into meiosis (13.5-15.5 dpc) and the second wave occurs between $17.5 \mathrm{dpc}$ and the day of birth marking the breakdown of cysts and the beginning of primordial follicle assembly (Coucouvanis et al. 1993, Ratts et al. 1995; Fig. 4). In humans, depletion of the germ cells occurs in the foetal ovary during midgestation, with apoptosis highest between weeks 14 and 28 and decreasing towards birth (Vaskivuo et al. 2001; Fig. 4). At birth, about two million oocytes are present, 400000 are left at puberty and 400 oocytes reach the ovulatory stage (Baker 1963). The nonovulatory follicles undergo apoptosis and become atretic. Although the process of apoptosis is crucial for regulating oocyte number, its genetic control is just starting to become clear as a consequence of studies in animal models.

Two apoptotic pathways have been identified: the extrinsic and the intrinsic or mitochondria-associated pathways (reviewed in Jaaskelainen et al. (2010)). Some of the extrinsic pathway factors are soluble or membrane-bound ligands such as FAS ligand, tumour necrosis factor $\alpha$ (TNFA) and TNF-related apoptosisinducing ligand (TRAIL/TNFSF10). The intrinsic pathway is operated by the B cell lymphoma-2 (Bcl2) family of cytoplasmic and mitochondrial proteins, which consists of anti-apoptotic $\left(B C / 2 / 1\left(B C l-X_{L}\right), B C l 2\right.$ and $\left.M c l 1\right)$ and proapoptotic (Bid, Bax, Bok and Bad) genes. The degree of apoptosis depends on the balance of these competing family members. The analysis of transgenic mouse models has identified various genes as regulating oocyte survival, apoptosis or cyst breakdown.

These include BCl2 (Ratts et al. 1995), Bax (Perez et al. 1999, Greenfeld et al. 2007) and caspase 2 (Casp2; Bergeron et al. 1998). Boumela et al. (2011) extensively reviewed the expression patterns of the human BCL2 members and found them to be differentially expressed during oocyte differentiation and early embryogenesis. The proapoptotic factor BAX was constitutively expressed in the oocyte and early embryo, suggesting that BAX poses a continuous death threat unless other prosurvival factors such as BCL2 inhibit its proapoptotic activity. Understanding the balance between the driving 
factors that cause an oocyte to undergo apoptosis or ensure its survival might give rise to potential biomarkers for oocyte quality and embryo developmental competence. A recent study using proteomic methodologies implicated proliferating cell nuclear antigen in promoting the apoptosis of oocytes in foetal and neonatal mouse ovaries (Xu et al. 2011).

Primordial follicles remain quiescent until selected follicles are activated to enter the first wave of follicle growth and commence the primordial-to-primary follicle transition (Hutt et al. 2006). These processes (reviewed in Uzumcu \& Zachow (2007)) mark the earliest stages of folliculogenesis and affect the duration of the female reproductive lifespan (Skinner 2005). Normal follicular development also requires cell-to-cell communication between the oocyte and the granulosa cells, as well as between the granulosa and the theca cells (Eppig 2001, Skinner 2005). Earlier studies implicated Kit ligand and c-Kit as intraovarian factors acting via phosphatidylinositol-3-kinase to control oocyte growth and early follicular development (reviewed in Liu et al. (2006)).

The following section will provide an update on current knowledge pertaining to factors regulating mammalian foetal ovarian development.

\section{Gene regulation and current mechanisms of ovarian development}

Mammalian ovarian development and differentiation are complex processes that involve crosstalk between the germ cell and somatic cell types. Since the early stages of ovarian differentiation are independent of pituitary gonadotrophins, it is important to understand the intraovarian factors that regulate the germ and somatic cell populations of the ovary. Genetically modified mouse models and mutation analysis in patients with ovarian disease have supplied a wealth of information. The following sections discuss the genetic regulation of foetal ovarian development and the molecular involvement of a number of genes in germ cell and somatic cell regulation.

\section{Germ cell regulation}

$D A Z L$ enables the gonads to respond to ovarian cues

Deleted in azoospermia-like (DAZL) protein is an RNAbinding protein first detected in PGCs after they have migrated into the gential ridges; it persists in the cytoplasm of adult germ cells (Cooke et al. 1996). The ovaries of adult Dazl knockout mice lack oocytes as a consequence of germ cell loss (at the time of entry into meiosis) during foetal development (McNeilly et al. 2000, Lin \& Page 2005). Expression pattern studies in the human foetal ovary indicated that immature germ cells express the pluripotency marker POU5F1, while the more mature germ cells such as oogonia (in cysts) or oocytes express DAZL and the germ cell marker VASA (Anderson et al. 2007). Recent in vivo genetic analysis of C57BL/6 DAZLdeficient foetuses found that germ cell specification and migration processes were not affected while the response to ovary and testis cues that determine sex were disrupted (Gill et al. 2011). This led to the proposal that DAZL plays a role in enabling the gonads to respond to masculinisation or feminisation cues.

\section{Factor in germ line $\alpha$ and a role in primordial follicle formation}

Factor in germ line $\alpha$ (Fig/ $\alpha$ ) gene is a basic helix-loophelix transcription factor required for ovarian follicle formation (Soyal et al. 2000). Figl $\alpha$ expression is detected in mouse oocytes from $13.0 \mathrm{dpc}$ and persists into adulthood where it acts as an activator of zona pellucida genes (Liang et al. 1997). Figl $\alpha$ is essential for follicle formation as Figl $\alpha$ female knockout mice fail to develop primordial follicles perinatally and are consequently sterile (Soyal et al. 2000). Adult females have small ovaries that contain only cord-like structures formed by somatic cells. In vitro culture of normal foetal ovarian cells at various developmental ages found Figl $\alpha$ to be one of the determining factors for germ cell survival and normal primordial follicle formation (Lei et al. 2006).

\section{Somatic cell regulation}

$R$-spondin, WNT4 and $\beta$-catenin: roles in the foetal ovary

R-spondin 1 (Rspo1) has a conserved role in ovarian differentiation during embryogenesis across species such as the mouse, chicken and turtle (Smith et al. 2008). Rspo1 was identified as an activator of the canonical WNT/ $\beta$-catenin signalling pathway. Mouse Rspo1 null $\mathrm{XX}$ ovaries display partially masculinised features including pseudohermaphroditism in genital ducts, depletion of foetal oocytes, male-specific coelomic vessel formation and ectopic testosterone production by the ovaries (Tomizuka et al. 2008). Loss-of-function mutations of the RSPO1 gene in humans cause testicular differentiation in 46, XX females (Parma et al. 2006, Chassot et al. 2008). A recent study showed that human RSPO1 is up-regulated during pregnancy between 6 and 9 weeks after conception, a time critical for early human ovary development (Tomaselli et al. 2011; Fig. 4).

Another gene implicated in ovarian development is Wnt4 that belongs to the wingless-type MMTV integration site family (WNT) of proteins. WNTs transduce their signals by binding to G-protein-coupled receptors of the Frizzled family to activate specific signalling pathways (Slusarski et al. 1997). Wnt4 is expressed in embryonic mouse ovaries, and loss-of-function mutations cause masculinised XX gonads in the mice (Heikkila et al. 2005). Expression of Wnt4 and its 
downstream genes were down-regulated in $\mathrm{Rspo}^{-1-}$ ovaries, suggesting that RSPO1 is positively regulating WNT4 signalling.

Both Rspo1 and Wnt4 exert their effects through $\beta$-catenin, a key transcriptional regulator and an intracellular mediator of the canonical WNT pathway. When $\beta$-catenin was ablated in the somatic cells of the foetal mouse ovary, female-to-male sex reversal was seen, with the loss of germ cells (Chassot et al. 2008). This phenotype is similar to that observed in the Wnt4 knockout ovary, suggesting that WNT4 and $\beta$-catenin operate via a common pathway that is essential for female germ cell survival (Vainio et al. 1999).

Ablation of Rspo1, Wnt4 and $\beta$-catenin genes induces development of seminiferous tubules in XX gonads (Chassot et al. 2008). It is thus postulated that these genes are required to suppress the male pathway in the $X X$ gonad and that their signalling is essential for normal embryonic ovarian development and in opposing testis development.

\section{The transforming growth factor $\beta$ signalling pathway}

The transforming growth factor $\beta$ (TGFB) superfamily of growth factors has been shown to play multiple roles in the local regulation of ovarian function (Knight \& Glister 2006). TGFB ligands act by binding to type II receptors, which recruit and phosphorylate type I receptors required for signal transduction. Binding of the ligands to the receptors is modulated by the non-signalling co-receptor betaglycan (TGFBR3; reviewed in Shi \& Massague (2003)). Signal transduction is then mediated by the mothers against decapentaplegic homologues (SMAD; Kaivo-oja et al. 2006). Members of the TGF family include TGFB1, 2 and 3, activins, inhibins and bone morphogenetic proteins (BMPs), all of which are expressed in somatic cells or oogonia during foetal and neonatal ovary development (Weng et al. 2006).

\section{Inhibins and activins}

Inhibins (inhibin $\alpha$ and either $\beta A$ or $\beta B$ subunits) and activins $\beta A$ and $\beta B$ (homodimers of inhibin $\beta$ subunits) have been characterised as gonadal-derived regulators of follicle-stimulating hormone ( $\mathrm{FSH}$; Risbridger et al. 2001). Inhibins and activins have been suggested to play autocrine and paracrine roles in steroidogenesis and folliculogenesis in the adult ovary (Findlay et al. 2000); their role in foetal ovarian development is becoming clearer. Inhibin $\beta A$ or $\beta B$, but not inhibin $\alpha$, subunit mRNA and protein are present in the human foetal ovary (Martins da Silva et al. 2004). In vitro culture of human foetal ovary with activin $A$ resulted in an increase in germ cell proliferation. When human recombinant activin A was administered in vivo to neonatal mice, there was an increase in prepubertal primordial follicle numbers (Bristol-Gould et al. 2006). Activin and TGFB receptors are expressed on both germ cells and somatic cells of the ovary (Findlay et al. 2002, Kaivo-oja et al. 2006), whereas the active phosphorylated SMADS 2 and 3, which activin signals through, are present only in somatic cells. Thus, foetal somatic cells are targets of activin action (Coutts et al. 2008). Low levels of inhibin $\alpha$ and activin $\beta A$ mRNA and protein were also detected in the stromal and granulosa cells of ovaries of foetal mice at $13.0 \mathrm{dpc}$ (Weng et al. 2006). Yao et al. (2006) established a role for activin $\beta B$ in the formation of the male-specific vasculature in $X Y$ gonads and identified it as a downstream target of Wnt4 and Fst (Yao et al. 2006). Analysis of a somatic cell-specific, $\beta$-catenin conditional knockout mouse model provided evidence for the importance of somatic cells to germ cell survival by balancing positive (Wnt $4 / \beta$-catenin) and negative (activin $\beta B$ ) germ cell regulators (Liu et al. 2010b), also reviewed in Liu et al. (2010a).

\section{Follistatin}

Fst binds activin with high affinity and is a key regulatory factor in the foetal ovary (Hemmati-Brivanlou et al. 1994). Inhibin, activin and Fst are all produced by the adult ovary, and they have the capacity to act as endocrine feedback signals that modulate pituitary FSH secretion (de Kretser \& Phillips 1998). Fst expression in the $X X$ foetal mouse gonad first appears at $11.5 \mathrm{dpc}$ and reaches its peak at $12.5 \mathrm{dpc}$ (Yao et al. 2004). From knockout mouse analysis, it has been established that Fst acts downstream of Wnt4 to suppress the male pathway and inhibit formation of the XY-specific coelomic vessel in XX gonads. In addition, Fst facilitates meiotic germ cell survival in the ovary; however, the exact mechanism of its action is still unclear. Fst-null mice lacking both isoforms of Fst (315 and 288) die at birth due to respiratory difficulties (Matzuk et al. 1995). Transgenic studies where the Fst knockout mice were rescued using human FST showed that Fst315 but not Fst288 rescued most of the defects of the Fst knockout (Lin et al. 2008). Another transgenic knockin study showed that Fst288 was able to rescue some of the defects and prevent prenatal death (Kimura et al. 2010). Further analysis of these Fst transgenic mouse models will identify the precise roles that Fst isoforms play in foetal ovarian development.

\section{Anti-Müllerian hormone}

Anti-Müllerian hormone (AMH) or Müllerian inhibitory substance is another TGFB superfamily member involved in the regulation of folliculogenesis (Baarends et al. 1995). A clear role for AMH has been identified during male foetal sex differentiation. AMH expressed by the testicular Sertoli cells causes the regression of the Müllerian derivatives that form the anlagen of the female reproductive tract; $\mathrm{AMH}$ prevents the development of the fallopian tube, uterus, cervix and upper vagina (Behringer 1994, Josso \& di Clemente 1997). AMH is unlikely to play a direct role in foetal ovarian 
development as no expression of $\mathrm{AMH}$ has been reported in the foetal mouse ovary; AMH is first detected in ovarian granulosa cells about 4 days after birth, at the onset of primary follicle formation (Durlinger et al. 2002). Recently, AMH was found to inhibit primordial follicle assembly in neonatal rat ovaries cultured in vitro (Nilsson et al. 2011). This same study found that $\mathrm{AMH}$ was expressed in the stromal tissue of the rat ovary during the postnatal stages of development, suggesting that stromal-epithelial interactions are required for primordial follicle assembly. In rodents, sheep and humans, AMH mRNA and protein were found to be expressed in granulosa cells of developmentally advanced follicles indicating a role in folliculogenesis (Baarends et al. 1995).

\section{FOXL2: a key regulator of ovarian development}

Another factor involved in ovarian differentiation is FOXL2, a member of the forkhead/HNF-3-related transcription factor family. FOXL2 is highly conserved and plays roles in cellular differentiation and development. In the adult human ovary, FOXL2 mutations result in premature ovarian failure (POF; Crisponi et al. 2001). FOXL2 has also been implicated in induction of female sex determination and follicle formation (Fig. 5). Foxl2 expression is first detected in mouse ovarian somatic cells around $13.0 \mathrm{dpc}$, when the germ cells enter meiosis. In the ovaries of Foxl2-null mice, somatic cells fail to develop around growing oocytes preventing follicle formation (Uda et al. 2004, Ottolenghi et al. 2005). A recent microarray study compared ovarian transcriptomes from wild-type mice and mice lacking Fox 12, Wnt4 or both genes to elucidate the role of these factors in gonadal development (Garcia-Ortiz et al. 2009). Analysis of the microarray data sets showed that loss of Foxl2 caused expression changes in different pathways to those observed in the Wnt4-null ovaries. These findings suggest that FOXL2 acts independently of the WNT4 pathway, but both are essential for normal ovarian development. Further studies of this type will help to elucidate the genetic basis of female fertility and identify candidate genes and pathways involved in ovarian development.

\section{The foetal ovary and the origins of disease hypothesis}

Barker (1994) first espoused his 'foetal origins of disease' hypothesis after correlating low birth weight with the development of cardiovascular disease in adult life. In recent years, the hypothesis has been extended to include any insult that affects the foetal environment leading to maladaptive responses by the foetus, which engenders the propagation of disease in later life. Smoking, poor nutrition, pollution, pesticides, radiation, infection, drugs, etc. have been shown to be detrimental to foetal development (reviewed in de Boo \& Harding
(2006), Edwards \& Myers (2007), Swanson et al. (2009), Wadhwa et al. (2009) and Langley-Evans \& McMullen (2010)). More recently, assisted reproductive technologies and obesity have been added to this list (Rinaudo \& Lamb 2008, Freeman 2010). The programming mechanisms by which these changes are affected is not clear, although a number of hypotheses have been proposed, notably the thrifty phenotype, oxidative stress, catch-up growth and epigenetic changes that might incorporate DNA methylation or histone acetylation (Edwards \& Myers 2007, Godfrey et al. 2010, Luo et al. 2010).

The effect of the nutritional environment during the foetal period on reproductive health and fertility in later life has been investigated in a range of species. Studies by Engelbregt et al. (2002) investigated whether compromised nutrition during the foetal or postnatal period influenced ovarian development in the rat. The ovaries of postnatally undernourished rats stimulated with pregnant mare serum gonadotrophin contained more primordial follicles but fewer antral follicles and corpora lutea, suggesting that follicle maturation was impaired. In contrast, rats assigned to intrauterine growth restriction (IUGR) protocols experienced delayed puberty and their ovaries contained fewer follicles (of all types) compared with controls (Engelbregt et al. 2002). Studies analysing foetal human tissue post-mortem found no effect of IUGR on ovarian development (de Bruin et al. 2001). In 2009, a review undertaken by Gardner et al. (2009) to assess whether foetal under-nutrition correlated with fecundity and fertility in humans, primates, rodents and sheep concluded that there was insufficient evidence to support such a claim.

Polycystic ovarian syndrome (PCOS) is estimated to affect up to $18 \%$ of women of reproductive age (March et al. 2010) and is the most common cause of infertility. Heterogeneous in presentation, PCOS features include anovulation, polycystic ovaries, hyperandrogenism, elevated levels of LH, insulin resistance, dyslipidemia and obesity (review in Teede et al. (2010)). In addition, individuals with PCOS manifest an increased lifetime risk of type II diabetes, cardiovascular disease and endometrial cancer (Ehrmann et al. 2005). The origins of PCOS have been proposed to extend back to foetal life. Exposure to androgens during gestation led to the development of PCOS by female rhesus monkeys (Abbott et al. 2009), sheep (Veiga-Lopez et al. 2008) and rats (Demissie et al. 2008), with characteristics similar to those observed in humans. Interestingly, treatment of adult monkeys with androgens in various forms and regimens failed to induce PCOS (Billiar et al. 1985). An association between low birthweight and PCOS has been reported in human studies (lbanez et al. 1998, Pandolfi et al. 2008), although more comprehensive analyses failed to support these findings (Sadrzadeh et al. 2003, Legro et al. 2010). Fibrillin 3, an ECM protein that regulates TGFB bioactivity, has been shown 
to be expressed in the stroma of foetal ovaries during the period when follicles are forming (Hatzirodos et al. 2011). The authors postulate that expression of fibrillin 3 at this time may predispose the foetus to develop PCOS in later life. To prevent the propagation of PCOS or metabolic-related disorders from mothers to daughters, interventions to prevent increased weight gain/adiposity during adolescence have been proposed (Abbott et al. 2009).

Ovarian cancer is a heterogeneous disease, the subtypes of which are epithelial, germ cell and sexcord stromal. Epithelial ovarian cancer (EOC) accounts for $90 \%$ of all ovarian cancers with serous, mucinous, endometrioid, clear-cell and transitional (Brenner) subtypes described on the basis of morphology. The origins of EOC remain unclear. Previously, the ovarian surface epithelium was thought to be the precursor for EOC, but in recent times, non-ovarian tissues such as the fallopian tube, peritoneum and endometrium have been touted as giving rise to specific subsets of EOC based on the tissue the cancer most resembles with (Kurman \& Shih le 2010). If this is indeed the case, then the only primary ovarian cancers are gonadal stromal (granulosa cell tumours) and germ cell tumours. While the origins of ovarian cancer are not clear, a number of risk factors have been identified, these include early menarche, nulliparity and infertility (Beral et al. 1978, Whittemore et al. 1989, Barker et al. 1995). More recently, exposure of the foetus in utero to environmental toxins (chemicals, pesticides, etc.) has been espoused to increase cancer risk (Perera 2011), supporting the developmental origins of disease hypothesis. Barker et al. (2008) proposed that ovarian cancer is initiated by exposure of the foetal ovary to maternal sex hormones, notably gonadotrophins (Barker et al. 1995). Concentrations of these hormones may be higher in mothers who have had an early menarche. A higher rate of weight gain during infancy has also been linked to ovarian cancer.

The germ line stem cell hypothesis proposed by Johnson et al. (2004) called into question one of the basic tenets of female reproduction, that of the finite ovarian reserve. It is difficult to assimilate their hypothesis with the phenomena of the menopause, POF and infertility caused as a consequence of chemotherapy. If there were indeed stem cells in the ovary, one might expect them to be activated to produce more oocytes under these circumstances? Since 2004, there have been a number of studies investigating this claim and purporting to either support or refute the hypothesis (for a review, see Notarianni (2011)). In the context of the foetal origin hypothesis, one might suggest that any insult directly affecting oocyte numbers during foetal development would be remedied by activating germ line stem cells. To date, there have been no studies that address this supposition or investigate whether POF arises as a consequence of unfavourable conditions during the foetal period.

\section{Conclusion}

It is increasingly clear that the foetal environment and any protective measures the foetus invokes to maintain itself when exposed to detrimental stimuli will have repercussions in later life. Reproductive dysfunction may manifest in infertility, ovarian cancers or other ovarian disorders. There is still much to be learnt about the molecular mechanisms and genes involved in foetal ovarian development. For example, which gene regulation pathways are functionally active in the foetal ovary and at what points do these pathways intersect? There is also a need to identify cell-specific genes that could be used as markers for further study of ovarian developmental processes. The availability of novel transgenic mouse models and advanced technologies for detecting and sequencing genes will further our knowledge on foetal ovarian development and contribute new data to be assessed in light of the origins of adult disease hypothesis. Further knowledge is also required in the area of the somatic cell contribution to oocyte growth and loss. Questions such as 'how is cell death regulated?' and 'what determines the size of the primordial follicle pool in the ovary?' remain to be answered. Establishing the molecular basis of events that occur during foetal ovarian development will further our understanding of the factors that affect oocyte quality and quantity and lead to a better appreciation of the causes of infertility, ovarian diseases such as gonadal dysgenesis and reproductive disorders such as POF and PCOS.

\section{Declaration of interest}

The authors declare that there is no conflict of interest that could be perceived as prejudicing the impartiality of the review reported.

\section{Funding}

This review did not receive any specific grant from any funding agency in the public, commercial or not-for-profit sector.

\section{Acknowledgements}

We would like to thank the National Health \& Medical Research Council of Australia New Investigator grant \#550915 (M A Sarraj) and the Victorian Government's Operational Infrastructure Support Program. We are grateful to Drs Michelle Myers and Karla Hutt for their comments on the manuscript and to Sue Panckridge for her input into the figures. Figure 4 was modified from an original figure by Hamish Morgan. Data used in Figs 1 and 3 were audited at Prince Henry's Institute (PHI audit reference number 11-15). 


\section{References}

Abbott DH, Tarantal AF \& Dumesic DA 2009 Fetal, infant, adolescent and adult phenotypes of polycystic ovary syndrome in prenatally androgenized female rhesus monkeys. American Journal of Primatology $\mathbf{7 1}$ 776-784. (doi:10.1002/ajp.20679)

Adams IR \& McLaren A 2002 Sexually dimorphic development of mouse primordial germ cells: switching from oogenesis to spermatogenesis. Development 129 1155-1164.

Aitken RJ, Findlay JK, Hutt KJ \& Kerr JB 2011 Apoptosis in the germ line. Reproduction 141 139-150. (doi:10.1530/REP-10-0232)

Anderson R, Fassler R, Georges-Labouesse E, Hynes RO, Bader BL, Kreidberg JA, Schaible K, Heasman J \& Wylie C 1999 Mouse primordial germ cells lacking beta1 integrins enter the germline but fail to migrate normally to the gonads. Development 126 1655-1664.

Anderson RA, Fulton N, Cowan G, Coutts S \& Saunders PT 2007 Conserved and divergent patterns of expression of DAZL, VASA and OCT4 in the germ cells of the human fetal ovary and testis. BMC Developmental Biology 7 136. (doi:10.1186/1471-213X-7-136)

Baarends WM, Uilenbroek JT, Kramer P, Hoogerbrugge JW, van Leeuwen EC, Themmen AP \& Grootegoed JA 1995 Anti-Mullerian hormone and anti-Mullerian hormone type II receptor messenger ribonucleic acid expression in rat ovaries during postnatal development, the estrous cycle, and gonadotropin-induced follicle growth. Endocrinology 136 4951-4962. (doi:10.1210/en.136.11.4951)

Baker TG 1963 A quantitative and cytological study of germ cells in human ovaries. Proceedings of the Royal Society of London. Series B $\mathbf{1 5 8}$ 417-433. (doi:10.1098/rspb.1963.0055)

Barker DJ 1994 Maternal and fetal origins of coronary heart disease. Journal of the Royal College of Physicians of London 28 544-551.

Barker DJ, Winter PD, Osmond C, Phillips DI \& Sultan HY 1995 Weight gain in infancy and cancer of the ovary. Lancet 345 1087-1088. (doi:10. 1016/S0140-6736(95)90821-8)

Barker DJ, Osmond C, Thornburg KL, Kajantie E \& Eriksson JG 2008 A possible link between the pubertal growth of girls and ovarian cancer in their daughters. American Journal of Human Biology 20 659-662. (doi:10.1002/ajhb.20789)

Behringer RR 1994 The in vivo roles of Mullerian-inhibiting substance. Current Topics in Developmental Biology 29 171-187.

Beral V, Fraser P \& Chilvers C 1978 Does pregnancy protect against ovarian cancer? Lancet 1 1083-1087. (doi:10.1016/S0140-6736(78)90925-X)

Bergeron L, Perez GI, Macdonald G, Shi L, Sun Y, Jurisicova A, Varmuza S, Latham KE, Flaws JA, Salter JC et al. 1998 Defects in regulation of apoptosis in caspase-2-deficient mice. Genes and Development 12 1304-1314. (doi:10.1101/gad.12.9.1304)

Billiar RB, Richardson D, Anderson E, Mahajan D \& Little B 1985 The effect of chronic and acyclic elevation of circulating androstenedione or estrone concentrations on ovarian function in the rhesus monkey. Endocrinology 116 2209-2220. (doi:10.1210/endo-116-6-2209)

de Boo HA \& Harding JE 2006 The developmental origins of adult disease (Barker) hypothesis. Australian \& New Zealand Journal of Obstetrics \& Gynaecology 46 4-14. (doi:10.1111/j.1479-828X.2006.00506.x)

Borum K 1967 Oogenesis in the mouse. A study of the origin of the mature ova. Experimental Cell Research 45 39-47. (doi:10.1016/00144827(67)90110-3)

Boumela I, Assou S, Aouacheria A, Haouzi D, Dechaud H, De Vos J, Handyside A \& Hamamah S 2011 Involvement of BCL2 family members in the regulation of human oocyte and early embryo survival and death: gene expression and beyond. Reproduction 141 549-561. (doi:10.1530/ REP-10-0504)

Bowles J \& Koopman P 2007 Retinoic acid, meiosis and germ cell fate in mammals. Development 134 3401-3411. (doi:10.1242/dev.001107)

Bowles J, Knight D, Smith C, Wilhelm D, Richman J, Mamiya S, Yashiro K, Chawengsaksophak K, Wilson MJ, Rossant J, Hamada H \& Koopman P 2006 Retinoid signaling determines germ cell fate in mice. Science 312 596-600. (doi:10.1126/science.1125691)

Bristol-Gould SK, Kreeger PK, Selkirk CG, Kilen SM, Cook RW, Kipp JL, Shea LD, Mayo KE \& Woodruff TK 2006 Postnatal regulation of germ cells by activin: the establishment of the initial follicle pool. Developmental Biology 298 132-148. (doi:10.1016/j.ydbio.2006. 06.025) de Bruin JP, Nikkels PG, Bruinse HW, van Haaften M, Looman CW \& te Velde ER 2001 Morphometry of human ovaries in normal and growth-restricted fetuses. Early Human Development 60 179-192. (doi:10.1016/S0378-3782(00)00118-3)

Bullejos M \& Koopman P 2004 Germ cells enter meiosis in a rostro-caudal wave during development of the mouse ovary. Molecular Reproduction and Development 68 422-428. (doi:10.1002/mrd.20105)

Byskov AG 1986 Differentiation of mammalian embryonic gonad. Physiological Reviews 66 71-117.

Chassot AA, Ranc F, Gregoire EP, Roepers-Gajadien HL, Taketo MM, Camerino G, de Rooij DG, Schedl A \& Chaboissier MC 2008 Activation of beta-catenin signaling by Rspo1 controls differentiation of the mammalian ovary. Human Molecular Genetics 17 1264-1277. (doi:10.1093/hmg/ddn016)

Childs AJ, Cowan G, Kinnell HL, Anderson RA \& Saunders PT 2011 Retinoic acid signalling and the control of meiotic entry in the human fetal gonad. PLoS ONE 6 e20249. (doi:10.1371/journal.pone.0020249)

Cooke HJ, Lee M, Kerr S \& Ruggiu M 1996 A murine homologue of the human DAZ gene is autosomal and expressed only in male and female gonads. Human Molecular Genetics 5 513-516. (doi:10.1093/ hmg/5.4.513)

Coucouvanis EC, Sherwood SW, Carswell-Crumpton C, Spack EG \& Jones PP 1993 Evidence that the mechanism of prenatal germ cell death in the mouse is apoptosis. Experimental Cell Research 209 238-247. (doi:10.1006/excr.1993.1307)

Coutts SM, Childs AJ, Fulton N, Collins C, Bayne RA, McNeilly AS \& Anderson RA 2008 Activin signals via SMAD2/3 between germ and somatic cells in the human fetal ovary and regulates kit ligand expression. Developmental Biology 314 189-199. (doi:10.1016/j. ydbio.2007.11.026)

Crisponi L, Deiana M, Loi A, Chiappe F, Uda M, Amati P, Bisceglia L, Zelante L, Nagaraja R, Porcu S et al. 2001 The putative forkhead transcription factor FOXL2 is mutated in blepharophimosis/ptosis/epicanthus inversus syndrome. Nature Genetics 27 159-166. (doi:10.1038/ 84781)

Demissie M, Lazic M, Foecking EM, Aird F, Dunaif A \& Levine JE 2008 Transient prenatal androgen exposure produces metabolic syndrome in adult female rats. American Journal of Physiology. Endocrinology and Metabolism 295 E262-E268. (doi:10.1152/ajpendo.90208.2008)

Durlinger AL, Gruijters MJ, Kramer P, Karels B, Ingraham HA, Nachtigal MW, Uilenbroek JT, Grootegoed JA \& Themmen AP 2002 Anti-Mullerian hormone inhibits initiation of primordial follicle growth in the mouse ovary. Endocrinology 143 1076-1084. (doi:10.1210/en. 143.3.1076)

Edinger AL \& Thompson CB 2004 Death by design: apoptosis, necrosis and autophagy. Current Opinion in Cell Biology 16 663-669. (doi:10.1016/j. ceb.2004.09.011)

Edson MA, Nagaraja AK \& Matzuk MM 2009 The mammalian ovary from genesis to revelation. Endocrine Reviews 30 624-712. (doi:10.1210/er. 2009-0012)

Edwards TM \& Myers JP 2007 Environmental exposures and gene regulation in disease etiology. Environmental Health Perspectives 115 1264-1270. (doi:10.1289/ehp.9951)

Ehrmann DA, Kasza K, Azziz R, Legro RS \& Ghazzi MN 2005 Effects of race and family history of type 2 diabetes on metabolic status of women with polycystic ovary syndrome. Journal of Clinical Endocrinology and Metabolism 90 66-71. (doi:10.1210/jc.2004-0229)

Eicher EM \& Washburn LL 1986 Genetic control of primary sex determination in mice. Annual Review of Genetics 20 327-360. (doi:10.1146/annurev.ge.20.120186.001551)

Engelbregt MJ, van Weissenbruch MM, Popp-Snijders C \& Delemarre-van de Waal HA 2002 Delayed first cycle in intrauterine growth-retarded and postnatally undernourished female rats: follicular growth and ovulation after stimulation with pregnant mare serum gonadotropin at first cycle. Journal of Endocrinology 173 297-304. (doi:10.1677/joe.0. 1730297)

Eppig JJ 2001 Oocyte control of ovarian follicular development and function in mammals. Reproduction 122 829-838. (doi:10.1530/rep.0. 1220829)

Findlay JK, Drummond AE, Britt KL, Dyson $M$, Wreford NG, Robertson DM, Groome NP, Jones ME \& Simpson ER 2000 The roles 
of activins, inhibins and estrogen in early committed follicles. Molecular and Cellular Endocrinology 163 81-87. (doi:10.1016/S0303-7207 (99)00243-9)

Findlay JK, Drummond AE, Dyson ML, Baillie AJ, Robertson DM \& Ethier JF 2002 Recruitment and development of the follicle; the roles of the transforming growth factor-beta superfamily. Molecular and Cellular Endocrinology 191 35-43. (doi:10.1016/S0303-7207(02)00053-9)

Freeman DJ 2010 Effects of maternal obesity on fetal growth and body composition: implications for programming and future health. Seminars in Fetal \& Neonatal Medicine 15 113-118. (doi:10.1016/j.siny. 2009.09.001)

Garcia-Ortiz JE, Pelosi E, Omari S, Nedorezov T, Piao Y, Karmazin J, Uda M, Cao A, Cole SW, Forabosco A et al. 2009 Foxl2 functions in sex determination and histogenesis throughout mouse ovary development. BMC Developmental Biology 9 36. (doi:10.1186/1471-213X-9-36)

Gardner DS, Ozanne SE \& Sinclair KD 2009 Effect of the early-life nutritional environment on fecundity and fertility of mammals. Philosophical Transactions of the Royal Society of London. Series B, Biological sciences 364 3419-3427. (doi:10.1098/rstb.2009.0121)

Gill ME, Hu YC, Lin Y \& Page DC 2011 Licensing of gametogenesis, dependent on RNA binding protein DAZL, as a gateway to sexual differentiation of fetal germ cells. PNAS 108 7443-7448. (doi:10.1073/ pnas.1104501108)

Godfrey KM, Gluckman PD \& Hanson MA 2010 Developmental origins of metabolic disease: life course and intergenerational perspectives. Trends in Endocrinology and Metabolism 21 199-205. (doi:10.1016/j.tem. 2009.12.008)

Gondos B 1987 Comparative studies of normal and neoplastic ovarian germ cells: 2. Ultrastructure and pathogenesis of dysgerminoma. International Journal of Gynecological Pathology 6 124-131. (doi:10.1097/00004347198706000-00004)

Gougeon A 1996 Regulation of ovarian follicular development in primates: facts and hypotheses. Endocrine Reviews 17 121-155.

Greenfeld CR, Pepling ME, Babus JK, Furth PA \& Flaws JA 2007 BAX regulates follicular endowment in mice. Reproduction 133 865-876. (doi:10.1530/REP-06-0270)

Hartshorne GM, Lyrakou S, Hamoda H, Oloto E \& Ghafari F 2009 Oogenesis and cell death in human prenatal ovaries: what are the criteria for oocyte selection? Molecular Human Reproduction 15 805-819. (doi:10.1093/molehr/gap055)

Hatzirodos N, Bayne RA, Irving-Rodgers HF, Hummitzsch K, Sabatier L, Lee S, Bonner W, Gibson MA, Rainey WE, Carr BR et al. 2011 Linkage of regulators of TGF-\{beta\} activity in the fetal ovary to polycystic ovary syndrome. FASEB Journal 25 2256-2265. (doi:10.1096/fj.11-181099)

Hawkins NC, Thorpe J \& Schupbach T 1996 Encore, a gene required for the regulation of germ line mitosis and oocyte differentiation during Drosophila oogenesis. Development 122 281-290.

Heikkila M, Prunskaite R, Naillat F, Itaranta P, Vuoristo J, Leppaluoto J, Peltoketo H \& Vainio S 2005 The partial female to male sex reversal in Wnt-4-deficient females involves induced expression of testosterone biosynthetic genes and testosterone production, and depends on androgen action. Endocrinology 146 4016-4023. (doi:10.1210/en. 2005-0463)

Hemmati-Brivanlou A, Kelly OG \& Melton DA 1994 Follistatin, an antagonist of activin, is expressed in the Spemann organizer and displays direct neuralizing activity. Cell 77 283-295. (doi:10.1016/00928674(94)90320-4)

Hutt KJ, McLaughlin EA \& Holland MK 2006 Primordial follicle activation and follicular development in the juvenile rabbit ovary. Cell Tissue Research 326 809-822. (doi:10.1007/s00441-006-0223-3)

Huynh KD \& Lee JT 2001 Imprinted X inactivation in eutherians: a model of gametic execution and zygotic relaxation. Current Opinion in Cell Biology 13 690-697. (doi:10.1016/S0955-0674(00)00272-6)

Ibanez L, Potau N, Francois I \& de Zegher F 1998 Precocious pubarche, hyperinsulinism, and ovarian hyperandrogenism in girls: relation to reduced fetal growth. Journal of Clinical Endocrinology and Metabolism 83 3558-3562. (doi:10.1210/jc.83.10.3558)

Jaaskelainen $M$, Nieminen A, Pokkyla RM, Kauppinen M, Liakka A, Heikinheimo M, Vaskivuo TE, Klefstrom J \& Tapanainen JS 2010 Regulation of cell death in human fetal and adult ovaries - role of Bok and $\mathrm{BCl}-\mathrm{X}(\mathrm{L})$. Molecular and Cellular Endocrinology 330 17-24. (doi:10. 1016/j.mce.2010.07.020)
Jenuth JP, Peterson AC, Fu K \& Shoubridge EA 1996 Random genetic drift in the female germline explains the rapid segregation of mammalian mitochondrial DNA. Nature Genetics 14 146-151. (doi:10.1038/ ng1096-146)

Johnson J, Canning J, Kaneko T, Pru JK \& Tilly JL 2004 Germline stem cells and follicular renewal in the postnatal mammalian ovary. Nature $\mathbf{4 2 8}$ 145-150. (doi:10.1038/nature02316)

Josso N \& di Clemente N 1997 Serine/threonine kinase receptors and ligands. Current Opinion in Genetics \& Development 7 371-377. (doi:10.1016/S0959-437X(97)80151-7)

Kaivo-oja N, Jeffery LA, Ritvos O \& Mottershead DG 2006 Smad signalling in the ovary. Reproductive Biology and Endocrinology 4 21. (doi:10. 1186/1477-7827-4-21)

Kimura F, Sidis Y, Bonomi L, Xia Y \& Schneyer A 2010 The follistatin-288 isoform alone is sufficient for survival but not for normal fertility in mice. Endocrinology 151 1310-1319. (doi:10.1210/en.2009-1176)

de Kretser DM \& Phillips DJ 1998 Mechanisms of protein feedback on gonadotropin secretion. Journal of Reproductive Immunology 39 1-12. (doi:10.1016/S0165-0378(98)00025-4)

Knight PG \& Glister C 2006 TGF-beta superfamily members and ovarian follicle development. Reproduction 132 191-206. (doi:10.1530/rep.1. 01074)

Koopman P 1992 Mammalian sex-determining genes. Current Opinion in Biotechnology 3 603-606. (doi:10.1016/0958-1669(92)90003-2)

Koubova J, Menke DB, Zhou Q, Capel B, Griswold MD \& Page DC 2006 Retinoic acid regulates sex-specific timing of meiotic initiation in mice. PNAS 103 2474-2479. (doi:10.1073/pnas.0510813103)

Kumar S, Chatzi C, Brade T, Cunningham TJ, Zhao X \& Duester G 2011 Sex-specific timing of meiotic initiation is regulated by Cyp26b1 independent of retinoic acid signalling. Nature Communications 2 151. (doi:10.1038/ncomms1136)

Kurman RJ \& Shih le M 2010 The origin and pathogenesis of epithelial ovarian cancer: a proposed unifying theory. American Journal of Surgical Pathology 34 433-443. (doi:10.1097/PAS.0b013e3181cf3d79)

Langley-Evans SC \& McMullen S 2010 Developmental origins of adult disease. Medical Principles and Practice : International Journal of the Kuwait University, Health Science Centre 19 87-98.

Lawson KA \& Hage WJ 1994 Clonal analysis of the origin of primordial germ cells in the mouse. Ciba Foundation Symposium 182 68-84 discussion 84-91.

Legro RS, Roller RL, Dodson WC, Stetter CM, Kunselman AR \& Dunaif A 2010 Associations of birthweight and gestational age with reproductive and metabolic phenotypes in women with polycystic ovarian syndrome and their first-degree relatives. Journal of Clinical Endocrinology and Metabolism 95 789-799. (doi:10.1210/jc.2009-1849)

Lei L, Zhang H, Jin S, Wang F, Fu M, Wang H \& Xia G 2006 Stage-specific germ-somatic cell interaction directs the primordial folliculogenesis in mouse fetal ovaries. Journal of Cellular Physiology 208 640-647. (doi:10. 1002/jcp.20702)

Liang L, Soyal SM \& Dean J 1997 FlGalpha, a germ cell specific transcription factor involved in the coordinate expression of the zona pellucida genes. Development 124 4939-4947.

Lin Y \& Page DC 2005 Dazl deficiency leads to embryonic arrest of germ cell development in XY C57BL/6 mice. Developmental Biology 288 309-316. (doi:10.1016/j.ydbio.2005.06.032)

Lin SY, Craythorn RG, O'Connor AE, Matzuk MM, Girling JE, Morrison JR \& de Kretser DM 2008 Female infertility and disrupted angiogenesis are actions of specific follistatin isoforms. Molecular Endocrinology 22 415-429. (doi:10.1210/me.2006-0529)

Liu K, Rajareddy S, Liu L, Jagarlamudi K, Boman K, Selstam G \& Reddy P 2006 Control of mammalian oocyte growth and early follicular development by the oocyte PI3 kinase pathway: new roles for an old timer. Developmental Biology 299 1-11. (doi:10.1016/j.ydbio.2006. 07.038)

Liu CF, Liu C \& Yao HH 2010a Building pathways for ovary organogenesis in the mouse embryo. Current Topics in Developmental Biology 90 263-290.

Liu CF, Parker K \& Yao HH 2010b WNT4/beta-catenin pathway maintains female germ cell survival by inhibiting activin betaB in the mouse fetal ovary. PLOS ONE 5 e10382. (doi:10.1371/journal.pone. 0010382) 
Luo ZC, Xiao L \& Nuyt AM 2010 Mechanisms of developmental programming of the metabolic syndrome and related disorders. World Journal of Diabetes 1 89-98. (doi:10.4239/wjd.v1.i3.89)

March WA, Moore VM, Willson KJ, Phillips DI, Norman RJ \& Davies MJ 2010 The prevalence of polycystic ovary syndrome in a community sample assessed under contrasting diagnostic criteria. Human Reproduction 25 544-551. (doi:10.1093/humrep/dep399)

Martins da Silva SJ, Bayne RA, Cambray N, Hartley PS, McNeilly AS \& Anderson RA 2004 Expression of activin subunits and receptors in the developing human ovary: activin A promotes germ cell survival and proliferation before primordial follicle formation. Developmental Biology 266 334-345. (doi:10.1016/j.ydbio.2003.10.030)

Matzuk MM \& Lamb DJ 2002 Genetic dissection of mammalian fertility pathways. Nature Cell Biology 4 s41-s49. (doi:10.1038/ncbnm-fertilityS41)

Matzuk MM, Lu N, Vogel H, Sellheyer K, Roop DR \& Bradley A 1995 Multiple defects and perinatal death in mice deficient in follistatin. Nature 374 360-363. (doi:10.1038/374360a0)

Mazaud S, Guyot R, Guigon CJ, Coudouel N, Le Magueresse-Battistoni B \& Magre S 2005 Basal membrane remodeling during follicle histogenesis in the rat ovary: contribution of proteinases of the MMP and PA families. Developmental Biology 277 403-416. (doi:10.1016/j.ydbio.2004.10. 001)

McElreavy K, Vilain E, Abbas N, Costa JM, Souleyreau N, Kucheria K, Boucekkine C, Thibaud E, Brauner R, Flamant F et al. 1992 XY sex reversal associated with a deletion $5^{\prime}$ to the SRY "HMG box" in the testisdetermining region. PNAS 89 11016-11020. (doi:10.1073/pnas.89.22. 11016)

McGee EA, Hsu SY, Kaipia A \& Hsueh AJ 1998 Cell death and survival during ovarian follicle development. Molecular and Cellular Endocrinology 140 15-18. (doi:10.1016/S0303-7207(98)00023-9)

McKearin D \& Ohlstein B 1995 A role for the Drosophila bag-of-marbles protein in the differentiation of cystoblasts from germline stem cells. Development 121 2937-2947.

McNeilly JR, Saunders PT, Taggart M, Cranfield M, Cooke HJ \& McNeilly AS 2000 Loss of oocytes in Dazl knockout mice results in maintained ovarian steroidogenic function but altered gonadotropin secretion in adult animals. Endocrinology 141 4284-4294. (doi:10. 1210/en.141.11.4284)

Motta PM, Nottola SA \& Makabe S 1997 Natural history of the female germ cell from its origin to full maturation through prenatal ovarian development. European Journal of Obstetrics, Gynecology, and Reproductive Biology 75 5-10. (doi:10.1016/S0301-2115(97)00216-9)

Nicholas CR, Haston KM \& Pera RA 2010 Intact fetal ovarian cord formation promotes mouse oocyte survival and development. $B M C$ Developmental Biology 10 2. (doi:10.1186/1471-213X-10-2)

Nilsson EE, Schindler R, Savenkova MI \& Skinner MK 2011 Inhibitory actions of Anti-Mullerian Hormone (AMH) on ovarian primordial follicle assembly. PLoS ONE 6 e20087. (doi:10.1371/journal.pone.0020087)

Notarianni E 2011 Reinterpretation of evidence advanced for neooogenesis in mammals, in terms of a finite oocyte reserve. Journal of Ovarian Research 4 1. (doi:10.1186/1757-2215-4-1)

Odor DL \& Blandau RJ 1969 Ultrastructural studies on fetal and early postnatal mouse ovaries. II. Cytodifferentiation. American Journal of Anatomy 125 177-215. (doi:10.1002/aja.1001250205)

Ottolenghi C, Omari S, Garcia-Ortiz JE, Uda M, Crisponi L, Forabosco A, Pilia G \& Schlessinger D 2005 Foxl2 is required for commitment to ovary differentiation. Human Molecular Genetics 14 2053-2062. (doi:10. 1093/hmg/ddi210)

Ottolenghi C, Uda M, Crisponi L, Omari S, Cao A, Forabosco A \& Schlessinger D 2007 Determination and stability of sex. Bioessays 29 15-25. (doi:10.1002/bies.20515)

Pandolfi C, Zugaro A, Lattanzio F, Necozione S, Barbonetti A, Colangeli MS, Francavilla S \& Francavilla F 2008 Low birth weight and later development of insulin resistance and biochemical/clinical features of polycystic ovary syndrome. Metabolism 57 999-1004. (doi:10.1016/j.metabol.2008.02.018)

Parma P, Radi O, Vidal V, Chaboissier MC, Dellambra E, Valentini S, Guerra L, Schedl A \& Camerino G 2006 R-spondin1 is essential in sex determination, skin differentiation and malignancy. Nature Genetics $\mathbf{3 8}$ 1304-1309. (doi:10.1038/ng1907)
Pauli D \& Mahowald AP 1990 Germ-line sex determination in Drosophila melanogaster. Trends in Genetics 6 259-264. (doi:10.1016/01689525(90)90208-N)

Pepling ME 2006 From primordial germ cell to primordial follicle: mammalian female germ cell development. Genesis 44 622-632. (doi:10.1002/dvg.20258)

Pepling ME \& Spradling AC 1998 Female mouse germ cells form synchronously dividing cysts. Development 125 3323-3328.

Pepling ME \& Spradling AC 2001 Mouse ovarian germ cell cysts undergo programmed breakdown to form primordial follicles. Developmental Biology 234 339-351. (doi:10.1006/dbio.2001.0269)

Pepling ME, de Cuevas M \& Spradling AC 1999 Germline cysts: a conserved phase of germ cell development? Trends in Cell Biology 9 257-262. (doi:10.1016/S0962-8924(99)01594-9)

Pepling ME, Sundman EA, Patterson NL, Gephardt GW, Medico L Jr \& Wilson KI 2010 Differences in oocyte development and estradiol sensitivity among mouse strains. Reproduction 139 349-357. (doi:10. 1530/REP-09-0392)

Perera F 2011 Molecular epidemiology, prenatal exposure and prevention of cancer. Environmental Health 10 (Suppl 1) S5. (doi:10.1186/1476069X-10-S1-S5)

Perez GI, Robles R, Knudson CM, Flaws JA, Korsmeyer SJ \& Tilly JL 1999 Prolongation of ovarian lifespan into advanced chronological age by Bax-deficiency. Nature Genetics 21 200-203. (doi:10.1038/5985)

Peters H, Byskov AG \& Grinsted J 1978 Follicular growth in fetal and prepubertal ovaries of humans and other primates. Clinics in Endocrinology and Metabolism 7 469-485. (doi:10.1016/S0300595X(78)80005-X)

Ratts VS, Flaws JA, Kolp R, Sorenson CM \& Tilly JL 1995 Ablation of bcl-2 gene expression decreases the numbers of oocytes and primordial follicles established in the post-natal female mouse gonad. Endocrinology 136 3665-3668. (doi:10.1210/en.136.8.3665)

Rinaudo PF \& Lamb J 2008 Fetal origins of perinatal morbidity and/or adult disease. Seminars in Reproductive Medicine 26 436-445. (doi:10.1055/ s-0028-1087109)

Risbridger GP, Schmitt JF \& Robertson DM 2001 Activins and inhibins in endocrine and other tumors. Endocrine Reviews 22 836-858. (doi:10. 1210/er.22.6.836)

Sadrzadeh S, Klip WA, Broekmans FJ, Schats R, Willemsen WN, Burger CW, Van Leeuwen FE \& Lambalk CB 2003 Birth weight and age at menarche in patients with polycystic ovary syndrome or diminished ovarian reserve, in a retrospective cohort. Human Reproduction 18 2225-2230. (doi:10.1093/humrep/deg409)

Shi Y \& Massague J 2003 Mechanisms of TGF-beta signaling from cell membrane to the nucleus. Cell 113 685-700. (doi:10.1016/S00928674(03)00432-X)

Sinclair AH, Berta P, Palmer MS, Hawkins JR, Griffiths BL, Smith MJ, Foster JW, Frischauf AM, Lovell-Badge R \& Goodfellow PN 1990 A gene from the human sex-determining region encodes a protein with homology to a conserved DNA-binding motif. Nature 346 240-244. (doi:10.1038/346240a0)

Skinner MK 2005 Regulation of primordial follicle assembly and development. Human Reproduction Update 11 461-471. (doi:10. 1093/humupd/dmi020)

Slusarski DC, Corces VG \& Moon RT 1997 Interaction of Wnt and a Frizzled homologue triggers G-protein-linked phosphatidylinositol signalling. Nature 390 410-413. (doi:10.1038/37138)

Smith CA, Shoemaker CM, Roeszler KN, Queen J, Crews D \& Sinclair AH 2008 Cloning and expression of R-Spondin1 in different vertebrates suggests a conserved role in ovarian development. BMC Developmental Biology 8 72. (doi:10.1186/1471-213X-8-72)

Soyal SM, Amleh A \& Dean J 2000 FIGalpha, a germ cell-specific transcription factor required for ovarian follicle formation. Development 127 4645-4654.

Spradling AC 1993 Germline cysts: communes that work. Cell 72 649-651. (doi:10.1016/0092-8674(93)90393-5)

Sugimoto M \& Abe K 2007 X chromosome reactivation initiates in nascent primordial germ cells in mice. PLoS Genetics 3 e116. (doi:10.1371/ journal.pgen.0030116)

Swanson JM, Entringer S, Buss C \& Wadhwa PD 2009 Developmental origins of health and disease: environmental exposures. Seminars in Reproductive Medicine 27 391-402. (doi:10.1055/s-0029-1237427) 
Tam PP \& Zhou SX 1996 The allocation of epiblast cells to ectodermal and germ-line lineages is influenced by the position of the cells in the gastrulating mouse embryo. Developmental Biology 178 124-132. (doi:10.1006/dbio.1996.0203)

Teede H, Deeks A \& Moran L 2010 Polycystic ovary syndrome: a complex condition with psychological, reproductive and metabolic manifestations that impacts on health across the lifespan. BMC Medicine 8 41. (doi:10.1186/1741-7015-8-41)

Tilly JL 2001 Commuting the death sentence: how oocytes strive to survive. Nature Reviews. Molecular Cell Biology 2 838-848. (doi:10.1038/ 35099086)

Tomaselli S, Megiorni F, Lin L, Mazzilli MC, Gerrelli D, Majore S Grammatico P \& Achermann JC 2011 Human RSPO1/R-spondin1 is expressed during early ovary development and augments beta-catenin signaling. PLoS ONE 6 e16366. (doi:10.1371/journal.pone.0016366)

Tomizuka K, Horikoshi K, Kitada R, Sugawara Y, Iba Y, Kojima A, Yoshitome A, Yamawaki K, Amagai M, Inoue A et al. 2008 R-spondin 1 plays an essential role in ovarian development through positively regulating Wnt-4 signaling. Human Molecular Genetics 17 1278-1291. (doi:10.1093/hmg/ddn036)

Uda M, Ottolenghi C, Crisponi L, Garcia JE, Deiana M, Kimber W, Forabosco A, Cao A, Schlessinger D \& Pilia G 2004 Foxl2 disruption causes mouse ovarian failure by pervasive blockage of follicle development. Human Molecular Genetics 13 1171-1181. (doi:10. 1093/hmg/ddh124)

Uzumcu M \& Zachow R 2007 Developmental exposure to environmental endocrine disruptors: consequences within the ovary and on female reproductive function. Reproductive Toxicology 23 337-352. (doi:10. 1016/j.reprotox.2006.10.006)

Vainio S, Heikkila M, Kispert A, Chin N \& McMahon AP 1999 Female development in mammals is regulated by Wnt-4 signalling. Nature 397 405-409. (doi:10.1038/17068)

Vaskivuo TE, Anttonen M, Herva R, Billig H, Dorland M, te Velde ER, Stenback F, Heikinheimo M \& Tapanainen JS 2001 Survival of human ovarian follicles from fetal to adult life: apoptosis, apoptosis-related proteins, and transcription factor GATA-4. Journal of Clinical Endocrinology and Metabolism 86 3421-3429. (doi:10.1210/jc.86.7.3421)

Veiga-Lopez A, Ye W, Phillips DJ, Herkimer C, Knight PG \& Padmanabhan V 2008 Developmental programming: deficits in reproductive hormone dynamics and ovulatory outcomes in prenatal, testosterone-treated sheep. Biology of Reproduction 78 636-647. (doi:10.1095/biolreprod.107.065904)
Villeneuve AM \& Hillers KJ 2001 Whence meiosis? Cell 106 647-650. (doi:10.1016/S0092-8674(01)00500-1)

Wadhwa PD, Buss C, Entringer S \& Swanson JM 2009 Developmental origins of health and disease: brief history of the approach and current focus on epigenetic mechanisms. Seminars in Reproductive Medicine 27 358-368. (doi:10.1055/s-0029-1237424)

Weng Q, Wang H, M SM, Jin W, Xia G, Watanabe G \& Taya K 2006 Expression of inhibin/activin subunits in the ovaries of fetal and neonatal mice. Journal of Reproduction and Development 52 607-616. (doi:10. 1262/jrd.18026)

Whittemore AS, Wu ML, Paffenbarger RS Jr, Sarles DL, Kampert JB, Grosser S, Jung DL, Ballon S, Hendrickson M \& Mohle-Boetani J 1989 Epithelial ovarian cancer and the ability to conceive. Cancer Research 49 4047-4052.

Woodruff TK \& Shea LD 2007 The role of the extracellular matrix in ovarian follicle development. Reproductive Sciences 14 6-10. (doi:10.1177/ 1933719107309818)

Wylie C 1999 Germ cells. Cell 96 165-174. (doi:10.1016/S00928674(00)80557-7)

Xu B, Hua J, Zhang Y, Jiang X, Zhang H, Ma T, Zheng W, Sun R, Shen W, Sha J et al. 2011 Proliferating cell nuclear antigen (PCNA) regulates primordial follicle assembly by promoting apoptosis of oocytes in fetal and neonatal mouse ovaries. PLOS ONE 6 e16046. (doi:10.1371/journal. pone.0016046)

Yao HH, Matzuk MM, Jorgez CJ, Menke DB, Page DC, Swain A \& Capel B 2004 Follistatin operates downstream of Wnt4 in mammalian ovary organogenesis. Developmental Dynamics 230 210-215. (doi:10.1002/ dvdy.20042)

Yao HH, Aardema J \& Holthusen K 2006 Sexually dimorphic regulation of inhibin beta B in establishing gonadal vasculature in mice. Biology of Reproduction 74 978-983. (doi:10.1095/biolreprod.105.050286)

Yoshimizu T, Obinata M \& Matsui Y 2001 Stage-specific tissue and cell interactions play key roles in mouse germ cell specification. Development 128 481-490.

Received 6 July 2011

First decision 1 August 2011

Revised manuscript received 10 November 2011

Accepted 21 November 2011 